Théologiques

Théologiques

\title{
Loving-Kindness towards Gentiles according to the Early Jewish Sages
}

\section{Joan Poulin}

Volume 11, numéro 1-2, automne 2003

Juifs et chrétiens. L’à-venir du dialogue.

URI : https://id.erudit.org/iderudit/009526ar

DOI : https://doi.org/10.7202/009526ar

Aller au sommaire du numéro

Éditeur(s)

Faculté de théologie de l'Université de Montréal

ISSN

1188-7109 (imprimé)

1492-1413 (numérique)

Découvrir la revue

Citer cet article

Poulin, J. (2003). Loving-Kindness towards Gentiles according to the Early Jewish Sages. Théologiques, 11(1-2), 89-112. https://doi.org/10.7202/009526ar d'utilisation que vous pouvez consulter en ligne.

https://apropos.erudit.org/fr/usagers/politique-dutilisation/ 


\title{
Loving-Kindness towards Gentiles according \\ to the Early Jewish Sages
}

\author{
Joan Poulin \\ Lecturer \\ University of Calgary
}

Christians often interpret Jesus' command to "love your neighbor" as an innovation. According to this view Judaism promotes a legalistic way of life, whereas Christianity teaches a doctrine of love and freedom. The roots of "love of neighbor" in the Hebrew Bible are overlooked, as is the possibility that kindness towards others was included in the development of post-biblical rabbinic Judaism. This paper will explore the concept of "love of neighbor" towards Jews and non-Jews as it was expressed by the Sages of Israel from the first to the sixth century ${ }^{1}$. The existence of positive rabbinic laws concerning non-Jews as far back as early rabbinic Judaism, may serve as a reminder in our own day, that the renewed respect and collaboration between Christians and Jews who face together the challenges of contemporary society are built on solid foundations.

The relationship between Jews and Gentiles during the first six centuries of the Common Era developed, to a great extent, within the radically changing political, economic and social circumstances in Roman Palestine. One of the greatest changes was the destruction of Jerusalem and the Temple in the first century that devastated Jewish life. Its preservation was insured by the codification of oral traditions, first in the Mishna (around $200 \mathrm{CE}$ ), and later in the Jerusalem and Babylonian Talmudim (between the 3rd and 6th centuries CE). As a consequence of these upheavals Jews came into more frequent and intimate contact with Gentiles. The Sages of Israel were confronted with the necessity of rethinking Jewish attitudes and conduct towards non-Jews. Aspects of

1. See the list of rabbinic works and the key for abbreviations at the end of this paper. 
Oral Law that touch on relations with Gentiles and, specifically, the concept of acts of "loving-kindness", gemilut hasadim, towards them became more relevant. The manner in which acts of loving-kindness are practiced towards Gentiles is not described in detail in oral tradition but since it is closely linked to how this mitzvah is practiced towards Jews, we will examine this question first and then draw a parallel to its practice towards Gentiles. The main texts dealing with "loving-kindness" towards Gentiles are from Palestinian Jewish sources, therefore a short summary of the changing population patterns in that area follows.

\section{Jews and Gentiles in Eretz Israel in the first six centuries CE}

Jew constituted the majority of the population in Palestine before the destruction of the Temple. They lived mainly in Judea, their lives controlled in religious-civil matters (courts, tithing) from Jerusalem.

The defeat of the Jews in two revolts against the Romans in the 1st and 2nd centuries of the Common Era accelerated the trend towards an intermingling of peoples that had begun with Alexander in the 4th c. BCE and continued with Pompey in the 1st c. BCE. Cities with predominantly Greek and Syrian populations were established along the Mediterranean coast and in the Decapolis, encircling Jewish areas. In the 1st c. CE, Jewish centers of population moved to the areas populated in large part by Gentiles and Gentiles were brought in to inhabit Judea. Hadrian transformed Jerusalem into a pagan city changing its name to Aelia Capitolina in the 2nd c. The Temple, the center of Jewish life and source of many social services for the poor and needy, no longer existed.

As the Gentile population increased, Jews were obliged to deal more frequently with them on a day-to-day basis. Indications that the Sages began to discuss seriously the question of relations between Jews and non-Jews as early as the beginning of the third century are found in the Mishna and in Tosephta ${ }^{2}$. Raphael Yankelevitch ${ }^{3}$ notes that at the end of

2. mTer. 1:1 (Gentiles and heave offerings); mShab. 16:6 (Gentiles extinguishing fires, lighting candles and drawing water for animals); tBer. 5:21 (Gentiles' ownership of land and duty of tithing); Pe'ah 2:9 (blessings said by a Gentile).

3. R. Yankelevitch, "The Relative Size of the Jewish and Gentile Populations in Eretz Israel in the Roman Period" in Cathedra (Hebrew), 61 (September 1991) p. 156-176, bases his estimate of the relative number of Jews to non-Jews in the 
the third century these discussions were in full swing. Emergency regulations were enacted to safeguard Jewish ownership of land, limit Jewish participation in Roman markets, and regulate social contacts with Gentiles. Roman fiscal policies and the breakdown of the tithing system connected with the Temple resulted in greater poverty within the Jewish community. As a result, the Sages were faced with the task of providing for the Jewish poor, and, as proximity with Gentiles became more common, of defining relations with them in greater detail, even in what concerned acts of charity. Within this context, the concept and practice of gemilut hasadim evolved first towards Jews and then was expanded to include Gentiles (bGit. 59b; bNez. 61a).

The Biblical basis for kindness towards others in Jewish Tradition is different for Jews and Gentiles. The precept of kindness towards "neighbor" in Jewish tradition is based on Lev. 19:18: "You shall not take vengeance or bear a grudge against the sons of your own people, but you shall love your neighbor as yourself, I am the Lord.” Interpretation of this verse in Jewish tradition, "neighbor" being connected with "the sons of your own people" suggests that "neighbor" is the Jewish person who shares the same Jewish religious values. Also included in the category of "neighbor" were Gentiles who observed the "laws of the sons of Noah", rules ordained by God for non-Jews according to Jewish tradition, or Gentile proselytes to Judaism who practiced some of the Jewish mitzvoth. Jews and Gentiles who lived according to the will of the Almighty, therefore, were "neighbor" or "brothers in the Torah and mitzvoth", whereas pagans, because of their idolatry and immoral conduct (in the eyes of Jewish observers) were not considered to be "neighbor" 4 .

country mainly on guidelines laid down by halakhah. In towns, which were exempt from the duty of paying certain taxes levied only on Jews, such as demai and ma'asarot, the Jews were a minority. Towns, which were not exempt, contained a Jewish majority. He estimates that two-thirds of the towns and cities in Eretz Israel after the two revolts had a foreign majority. The Christian scholar EusEbius (263$339 \mathrm{CE}$ ), in his Onomasticon and in The History of the Church also provides important information about the country and the number of its inhabitants in his day.

4. A brief comparison with the Christian concept of "love of neighbor", which also developed in this period might be useful, as this aspect of Jesus' teaching is sometimes considered by Christians to constitute the essential difference between Chris- 
The Scriptural basis for similar halakhot practiced towards Gentiles is not Lev. 19:18, but passages such as Mic. 6:8: "He has showed you, O man, what is good: and what the Lord requires of you: to do justice, to love kindness, and to walk humbly with your God." This text is linked with Gen. 18 where Abraham serves three strangers who visit his tent in Mamre.

Many texts in Oral Tradition describe details of acts of "lovingkindness," gemilut hasadim. In order to gain an understanding of the breadth and depth of this mitzvah, I will begin by reviewing the origins of the expression gemilut hasadim and the importance of this mitzvah, the manner in which it was practiced towards Jews, then draw a parallel with its practice towards Gentiles.

\section{Origins of the expression gemiluth hasadim and importance of this mitzvah}

Although based on Biblical tradition the expression gemilut hasadim does not appear in the biblical text. The two components of this expression gemel and hesed appear separately in several texts of Scripture. The verb gemel means to ripen (Is. 18:5), to bear fruit (Num. 17:8), or to wean (1 Sam. 1:22, Gen. 21:8). The term besed has a very rich range of meanings, which were explored by Nelson Glueck in his classic work, Hesed in the Bible 5 . The term implies the gratuitous generosity of the Almighty, and humankind's imitation of this freely bestowed kindness. Ps. 136 clearly expresses this lofty ideal in the phrase ki le 'olam hasdo,

tianity and Judaism. The concept of "neighbor" in the early church evolved away from its original meaning within the Judaism of that period. Early Christians understood "neighbor" in the light of the expansion of the Church into the Gentile, pagan world. In the writings of Paul from the first century, especially in the letter to the Galatians, the "charter" of Gentile Christianity, "neighbor" is applied to both Jews and Gentiles. The parable of the Good Samaritan (Luke 10), where Jesus quotes Deut. 6:4-5 (love of God) and Lev. 19:18 (love of neighbor), and then answers the question "and who is my neighbor?" with a story about the extraordinary kindness of a Samaritan, became the Christian paradigm for acts of kindness towards strangers. The Fathers of the Church and preachers throughout the centuries, down to our own day, continue to interpret "neighbor" as applying to the whole human race.

5. N. Glueck, Hesed in the Bible, Cincinnati, The Hebrew Union College Press, 1967. 
"for his loving mercy endures forever," which is repeated after the recitation of each miracle wrought by a loving God.

Gemel and hesed, separate ideas in Scripture, were combined in Oral Tradition to form one single concept, gemilut hasadim. In the tradition of the Sages it suggests a high degree of perfection in the performance of freely chosen acts of kindness towards one's fellow human beings in imitation of the Creator.

The importance of gemilut hasadim is demonstrated by the number of times it is mentioned in Oral Tradition and by the extraordinary language used to describe it in aggadic stories. In bHag. 12a, Rav (head of the academy at Sura, Babylon, in the 3rd c. CE) counts it among the ten things by which the world was created. Lev. R. 2:1 says it is among the ten yaqar, "precious," things in the world. The earliest mention of gemilut hasadim is attributed to Simon the Just, who lived in the 2nd c. BCE, long before the codification of the Mishnah: "The world rests on three things: on Torah, on Temple service and on gemilut hasadim ${ }^{6}$." Even after the destruction of the Temple when there was general religious disorientation among the Jews in Palestine, along with other things regarding the expiation of sins, R. Jonathan b. Zakkai reassured R. Joshua, as they walked together near the ruined Temple:

R. Joshua: Alas for [...] this place, where the iniquities of Israel were expiated $[\ldots]$.

R. Yohanan b. Zakkai: My son, be not grieved. We have a means of atonement that is its equal, namely the practice of benevolence, as it is said: "For I desire loving kindness, and not sacrifice" (Hos. 6:6). (A. de-R. Nathan 4,5.)

The most impressive indication of the importance of gemilut hasadim, according to the Sages, is that God himself gave us the example. R. Hama, son of R. Hanina, further said:

What means the text: "You shall walk after the Lord your God?" (Dt. 13:5) is it, then, possible for a human being to walk after the Shekhinah; for has it not been said, "for the Lord, thy God is a devouring fire?" (Dt. 4:24) But [the meaning is] to walk after the attributes of the Holy One, blessed by He, as he clothes the naked, for it is written: "and the Lord God

6. P.Avot 1:2; cf. Num. R. 12:12. 
made for Adam and for his wife coats of skin and clothed them" (Gen. 3:21). So do thou also clothe the naked. The Holy One, blessed by He, visited the sick, for it is written: "and the Lord appeared unto him by the oaks of Mamre” (Gen. 21:3) [while Abraham was recuperating from being circumcised]. So do thou also visit the sick. The Holy One, blessed by He, comforted mourners, for it is written: "and it came to pass after the death of Abraham, that God blessed Isaac, his son" (Gen. 25:2). So do thou also comfort mourners. The Holy One, blessed be He, buried the dead, for it is written: "and he buried him [Moses] in the valley" (Dt. 34:6). So do thou also bury the dead. (bSot. 14a)

From this passage we see that gemilut hasadim is the beginning and the end of Torah for it begins with the clothing of Adam and Eve and ends with the burial of Moses (bSanh. 46a).

\section{Gemilut hasadim towards Jews}

Four acts of loving-kindness are described in the previous Talmudic passage: to clothe the naked, visit the sick, comfort mourners, and bury the dead. Lending money, utensils or animals are also acts of gemilut hasadim (bKet. 72a), as well as providing food, drink and lodging for travelers, accompanying them on their journey (bShab. 126b-127a; bMen. 97a; mP.Avot 1:5,15), and providing dowries for brides (bSuk. 49b).

Intangible acts such as rejoicing with the bride and groom, consoling the poor and giving them good advice ${ }^{7}$, working for reconciliation between friends, praying for the cure of a sick person or for someone in trouble, causing others to donate to charity are all special characteristics of gemilut hasadim. According to bSuk. 49b another is teaching Torah: "Some say, Torah [which is studied] in order [subsequently] to teach it is a Torah of loving kindness..."; even teaching Torah to a non-Jew was commended (bAv.Zara 11a), although it was controversial, especially after Christianity began "appropriating" the biblical text.

Thoughtfulness for the special circumstances of each person, rich or poor $^{8}$, is included in this mitzvah. An example of concern for the special circumstances of others follows:

7. bB.B. 5a.; cf. bB.B. 9b where it is said that giving charity merits six blessings, but giving good advice merits eleven blessings.

8. bKet. 67b; cf. Sifrei Deut. (Behar) 24:1; Lev. R. 34:1. 
If an orphan boy and an orphan girl applied for maintenance, the girl orphan is maintained first and the boy afterwards. [...] If an orphan boy and an orphan girl applied for a marriage grant, the girl orphan is enabled to marry first. [...] If an orphan applied for assistance to marry, a house must be rented for him, a bed must be prepared and [he must also be supplied with] all [household] items [required for] his use, and then he is given a wife [...] You are commanded to maintain him [...] even a horse to ride upon and a slave to run before him. (bKet. 67a and b)

Some Sages advocated treating each person according to his needs or according to his life style. But bKet. $67 \mathrm{~b}$ expresses only conditioned agreement about this type of generosity. On one hand, in this passage a man accustomed to "fat meat and old wine" died as a result of sharing R. Nehemiah's lentils (!), but "he should not have cultivated his luxurious habits to such an extent." On the other hand, God himself provided a rich meal for Rava's hungry guest who was accustomed to eat well!

Although gemilut hasadim is very similar to tzedaka, "charity," subtle nuances differentiate the two mitzvoth:

Our Rabbis taught: In three respects is gemilut hasadim superior to charity. Charity can be done only with one's money, but gemilut hasadim can be done with one's person and one's money. Charity can be given only to the poor, gemilut hasadim both to rich and poor. Charity can be given to the living only, gemilut hasadim can be done both to the living and to the dead. (jPe'ah 15b-c)

The value of any action, whether it is the study of Torah, an act of gemilut hasadim, or plowing a field, depends on the good intention behind it. bBer. 17a attributes to the Sages of Yabneh a comparison between a farmer and a Torah scholar. Neither the amount of work accomplished by the farmer nor the number of books studied by the scholar increased their merit. Merit in the sight of God depends on the intention with which each act is accomplished. In this regard, bSuk. 49b states: "The reward of charity depends entirely on the extent of kindness in it." In bKet. 67a, Naqdimon b. Gorion's daughter was reduced to dire poverty because her father practiced charity for the wrong reasons: "He did it for his own glorification."

The unique nature of gemilut hasadim lies in a delicate balance between demands of the law of charity and personal initiative. The intangible spiritual dimension included in the practice of this mitzvah can neither be legislated not measured. The codifiers of halakhah interpreted 
Deut. 6:17: "You shall diligently keep the commandments of the Lord your God, and his testimonies, and his statutes, which he has commanded you", as a command to fulfill the regular mitzvoth. The following verse (18) "and you shall do what is right and good in the sight of the Lord..." is interpreted to mean going beyond the regular mitzvoth. Anyone who acts in this manner is considered a hasid, a saintly person. Although there is disagreement among the Sages about whether "going beyond the letter of the law" is itself a law or not, numerous examples in oral tradition portray the Sages practicing gemilut hasadim "beyond the requirement of the law". Hillel the Elder once hired a horse for a poor man of good family to ride for his wedding, and when he could not find a slave to ride in front of him, "he himself, ran before him for three miles" (bKet. 67b). bKet. 77b recounts that R. Joshua ben Levi sat with a man suffering from an infectious disease, even though several other Sages refused to do so. For this reason he was considered worthy to receive a special welcome from Elijah in the next world.

The practice of deeds of gemilut hasadim "beyond the requirements of the law" is in imitation of God's generosity. This is expressed in the name of Rav in bBer. 7a where the Almighty Himself prays: "May it be my will that My compassion may conquer My anger, and that My compassion may prevail over My other attributes, so that I may deal with My children mercifully and act towards them with charity that goes beyond the requirements of the law."

The rewards for acts of gemilut hasadim are impressive. According to Resh Lakish in bKet. $8 \mathrm{~b}$ and bBer. $8 \mathrm{a}$, God himself will reward in the next life those who practice this mitzvah. Unlimited benefits are accumulated for acts of gemilut hasadim in this life and in the next according to Pe'ah 1:1: it is among the: "...things for which a man enjoys the fruits in this world while the principal remains for him in the world to come."

The Mekhilta, tractate Amalek on Ex. 18:1 says that Jethro, Abraham, Sarah and Joshua each had a letter added to his/her name, which meant an additional degree of righteousness and honor, because of their acts of "loving-kindness."

\section{Gemilut hasadim towards Gentiles}

Jewish existence throughout the centuries emphasized resistance to contact with Gentiles because of their idol worship, pagan culture and negative moral values. Even at the beginning of the Common Era, Gentile 
peoples who lived in Palestine, as well as in Babylon, Asia Minor and the Mediterranean area, were considered idolaters. The Sages declared the Gentiles' temples, his home, markets and theatres, all providing a setting for pagan practices, were to be avoided.

At the same time, the changing configuration of the Gentile world, closer proximity between Jews and Gentiles, the growth of Christianity and the demise of idol worship confronted the Sages with new dilemmas. Halakhic decisions aimed at avoiding contact with Gentiles in sensitive areas, while at the same time living with them as neighbors, provided the dynamics within which relations with non-Jews evolved.

In the mind of the Sages however, there were various categories of Gentiles, each to be treated differently. Besides the general terms of goy and nokbri, the expression "sons of Noah" was used to designate righteous Gentiles who practiced the seven Noachite Laws, universal commandments given by God in the covenant with the whole human race after the flood. Ger or ger tzedeck was a Gentile who adopted all or some of the mitzvoth as a way of life. Ger toshav designated a Gentile who lived in the land of Israel and observed the "commandments of the sons of Noah" or some of the mitzvoth, without necessarily adopting the Jewish religion. The relations of the Jewish person to his/her Gentile interlocutor, depended, in any particular situation on several factors: the historical circumstances, the character of the Sage or of the Jewish person, the type of Gentile he/she was dealing with. According to Ephraim Urbach, "the type of Gentile that they encountered [...] determined the reaction of the sages." Against the view of R. Eliezer that "No Gentile has a share in the world to come," R. Joshua argued: "But there are righteous men among the nations who have a share in the world to come." (tSanh. 13:2) Probably the dictum "Even a Gentile who studies Torah is like the High Priest" is only the outcome of a positive experience". But at the same time R. Yohanan held: "A Gentile who studies Torah is deserving of death ${ }^{10}$."

9. E.E. Urbach, The Sages, their Concepts and Beliefs, Jerusalem, Magnes, 1987, p. 543-544. Cf. bB.B. 1a-b.

10. This is a good example of expressions in Oral Tradition that can only be understood in context. R. Yohanan lived in the middle of the 3rd c. when Christianity was in full expansion. M. ElON explains that expressions that display "disproportionate penalty" (e.g. "deserving of death") reveal the profound indignation of the 
Urbach continues by saying that this last probably refers to Christians "who sought to make the Torah their heritage," but even here, in actual practice, it seems that $\mathrm{R}$. Yohanan maintained "one should thrust them aside with the left hand and bring them near with the right ${ }^{11}$."

Along with the tendency to remain separate from the "nations of the world," a contrasting principle is discernible within Jewish tradition. The dignity of all human beings as creatures of God is expressed throughout halakhah and aggadah. In addition, the election of Israel implied the duty of witnessing to the sanctity of God's Name, qiddush ha-shem. This could be done by word and example, but also by dying for the preservation of the commandments. A well-known incident reveals the practice of qiddush ha-shem by example: Simon b. Shetah returned a donkey to the Gentile from whom he had bought it, after having discovered a concealed pearl in its saddle. His disciples were astonished that Shimon acted in this way towards a non-Jew. Simon, however, preferred to hear praise of God from a Gentile than to become wealthy (jB.M. 2:5,8c and Deut. R. 3:3). Simon's reputation for public witness towards Gentiles was proverbial.

\section{Texts in Oral Tradition dealing with Gemilut hasadim towards Gentiles}

We will now turn to the texts that deal with the practice of gemilut basadim. It is important to note that the passages that deal with the practice of gemilut hasadim towards Gentiles are unique in Talmudic literature in that, as far as I am aware, they are the only texts which draw a direct parallel between Jews and Gentiles.

The passages dealing with acts of loving-kindness towards Gentiles are formulated anonymously (rather than being in the name of one Sage or other) which, according to some scholars indicates their importance. The introductory expression tenei ("it has been taught in a tannaitic teaching") in the Jerusalem Talmud, and tenu rabannan ("our Sages

'amora'im for behavior for which the law could not apply a penalty. M. ELON, ed., The Principles of Jewish Law, Jerusalem, Encyclopedia Judaica, 1989.

11. Urbach, The Sages, p. 550. 
taught") in the Babylonian Talmud usually designate ancient traditions about which there is little disagreement ${ }^{12}$.

The five passages from Oral Tradition that lists acts of gemilut basadim towards Jews, surprisingly include Gentiles in the same verses. The list is almost the same in each source, but there are nuances between the four sources codified in Eretz Israel (Tosefta and the Jerusalem Talmud) and one codified in Babylon (the Babylonian Talmud) living conditions being different in each area.

We will begin with the passage from Tosefta, which is the oldest formulation of Oral Tradition, but was not included by Judah the Prince in his codification of the Mishnah in the second century.

\subsection{Tosefta, Gittin 3:13-14}

A city in which Israelites and Gentiles live, the collector of funds collects from Israelites and from Gentiles for the sake of peace. They provide support for the poor of the Gentiles for the sake of peace.

They lament Gentile dead and console Gentile mourners and bury Gentile dead, for the sake of peace.

\subsection{Jerusalem Talmud, Gittin 5:9, 47c}

Gentile poor are not prevented from gathering gleanings (Lev. 19:9), the forgotten sheaves (Deut. 24:19) and the corners of the fields (Lev. 19:9ff.).

For the sake of peace.

It has been taught in a tannaitic teaching, a city in which

Gentiles and Israelites live, collectors from among the Gentiles

and from Israel are named and funds are collected from Gentiles and from Israelites.

They provide for the poor of the Gentiles along with the poor of Israel.

They visit the sick of the Gentiles as well as the Israelite sick.

They bury the dead of the Gentiles as well as Israelite dead.

They comfort mourners of the dead of Gentiles as well as

Israelite mourners.

They bring in the utensils of Gentiles and the utensils of Israelites 
(support the brides of Gentiles as well as Israelite brides) - (all) on account of peace.

\subsection{Jerusalem Talmud, Demai 4:6,24a}

It has been taught in a tannaitic teaching,

A city in which Gentiles and Israelites live,

The collectors of funds collect from Israel and from Gentiles,

Support the poor of Israelites and the poor of Gentiles.

Support the brides of Gentiles and the brides of Israel.

(or "bring in the utensils of Gentiles and the utensils of Israel")

For the sake of peace.

Visit the sick of Israelites as well as the sick of Gentiles,

Bury the dead of Israelites as well as the dead of Gentiles,

Console Israelites mourners as well as the mourners among the

Gentiles.

A slight difference appears in the Jerusalem Talmud, Av.Zara 1:3, 39c, where it is stated that if Gentiles are ready to contribute, charity funds are collected from them, but there is no difference in the distribution of funds to Gentile poor.

\subsection{Jerusalem Talmud, Avodah Zara 1:3, 39c}

It has been taught in a tannaitic teaching

A city in which Gentile and Israelites live, if the Gentiles contribute to the charity collectors, they collect from them and from the Israelites.

They support the poor of Gentiles as well as the Israelite poor, And visit the sick of Gentiles as well as Israelite sick,

Comfort mourners among the Gentiles as well as Israelite mourners,

Bury the dead of Gentile as well as Israelite dead, They bring in the utensils of Gentiles as well as Israelite utensils

(support brides of Gentiles as well as Israelite brides),

For the sake of peace.

\subsection{Babylonian Talmud, Gittin 61 a}

The poor of the Gentiles are not prevented from gathering gleanings, 
forgotten sheaves and the corner of the field, for the sake of peace.

Our Sages taught:

We support the poor of Gentiles along with the poor of Israel, And visit the sick of Gentiles along with the sick of Israel

And bury the dead of Gentiles along with the dead of Israel ${ }^{13}$, In the interests of peace.

The mishnaic passage in $\mathrm{j}$ and bGit. is a negative formulation of Lev. 19:9 and Deut. 24:19 which discusses the gathering of the gleanings, forgotten sheaves, the corner of the field and extra grapes on the vine by the poor. The Biblical text's formulation, on the other hand, is positive: "You shall leave them (the corners of the fields and the forgotten sheaves) for the poor and for the sojourner." The negative formulation "they were not prevented" may indicate that since farmers harvested their fields in public, both Jewish and Gentile poor gathered what was left. It is difficult to imagine how a separation between the two could have been implemented without provoking not only hard feelings, but also on occasion violent reactions ${ }^{14}$. On the other hand, provisions for the poor, which were distributed in private such as the poor tithe, ma'asar sheni, "the second tithe ${ }^{15}$ ", or the fruits of the seventh year, were not usually distributed to Gentiles ${ }^{16}$. An added reason why the Gentile poor were not

12. M. Mielziner, Introduction to the Talmud, New York/London, Funk and Wagnalls Company, 1903, p. 220; C. Albeck, Introduction to the Talmud Babli and Yerushalmi, Tel Aviv, Devir Publishing House, 1987, p. 21-30; A. Carmell, Aiding Talmud Study, Jerusalem/New York, Geldheim, 1988, p. 71: "All baraitoth which are not contested in gemara are accepted as law."

13. The gemara in the Babylonian Talmud uses the preposition "im, "with," the dead of Israel, instead of vav, "and," as in the Jerusalem Talmud. The consensus of the Sages is that "im should be translated "as" we bury the dead of Israel, and not "with." Cf. Y. CoHEn, The Attitude of the Gentile in Halacha and in Reality in the Tannaitic Period. Thesis submitted for the degree "Doctor of Philosophy" to the Senate of the Hebrew University, Jerusalem, 1975, p. 280 (Hebr.).

14. Violent incidents are recorded in mPe'ah 4:3, tPe'ah 2:2, 4:2. mPe'ah 4:4 prohibits the poor from bringing utensils (scythes, sickles etc.) to the fields for fear of an outbreak among them. If this was true among the Jewish poor, how much more delicate must relations between Jews and Gentiles have been!

15. Deut. 14:28-29 and Sifrei Deut. (Re'eh) (ed. Finkelstein), p. 171.

16. Lev. 25:6, Siphra (Behar) 1:6, (ed. Weiss), p. 106 and tShevi'it 5, h. 1 (ed. Zuckermandel), p. 69. For a different version see S. Lieberman, Tosefta Kifshutah, New 
prevented from profiting from the harvest may have been the question of reciprocity. Jewish poor profited from the distributions of the Roman authorities in some areas, or in later centuries from Christians, who began to distribute funds with increased frequency. Under these circumstances the Jewish community may have felt obliged to provide equally for Jewish and Gentile poor. It is interesting to note that the other acts of gemilut hasadim are all formulated in a positive way.

Sources codified in Eretz Israel, Tosefta and the Jerusalem Talmud, begin with the formula "A city where Jews and Gentiles live..." The Babylonian Talmud omits this sentence since Jews in Babylon lived a relatively autonomous life in this period. Only in Palestine did some cities still contain a Jewish majority ${ }^{17}$. The phrase does not refer to the many cities where Jews were a minority even though in these cities Jews held public office in the Roman administration and served on city councils in Gentile towns. In the latter case Jewish officials were not usually in complete control of charity funds. Although the Tosefta text mentions collecting from Jews and Gentiles, it is the only passage that does not draw a parallel between doing acts of loving-kindness to Jews and to Gentiles.

Another characteristic of the passage in Tosefta is that only here is besped, "lamenting/eulogizing or mourning" Gentile dead mentioned. The Jerusalem and Babylonian Talmudim speak only about burying Gentile dead and consoling Gentile mourners. Tractate Berakhot in both the Jerusalem (2:8) and Babylonian (16b) Talmudim speak about the treatment of slaves who have died: "There is no standing in line, no

York, 1955, vol. II, p. 560, which says that in the Vienna manuscripts there is a reference to soldiers billeted in Jewish homes who were permitted to eat the sabbatical fruits because they were considered to be "members of the household," benei betkha. Gentiles not "members of the household," were not permitted to partake of the seventh-year fruits.

17. Epiphanius (Christian writer who lived in Palestine around 315-403 CE) says in Panarion Haer, 30:3-4; 30:12-9: “... for they [Jews] have among them neither Hellene nor Samaritan nor Christian. This is a matter about which they are very particular, especially in Tiberias and in Diocesarea-which is Sepphoris-and in Nazareth and Capharnaum, desiring that no Gentile should be found there." G. Alon notes that EpIPHANius may have been exaggerating since passages in the gemarah speak of Gentiles in Tiberias (The Jews in their Land in the Talmudic Age, Jerusalem, Magnes, 1980, 2 vols., p. 753). 
consoling, no mourning and no eulogizing male and female slaves," but there is no indication if the slaves are Jews or Gentiles. In a minor tractate, $S^{e}$ mahot, which deals with burial rites, echoes the same idea, but adds "non-Jews" to "slaves." It states in 44a: "For a non-Jew or a slave we do not occupy ourselves with his funeral rites, but we exclaim of him, 'Alas Lion, Alas mighty man'!", which might indicate an expression of mourning or eulogy.

It is difficult to reconcile these contradictory statements from different sources. A few remarks on this subject, however, might be in order. Perhaps the $S^{e}$ mahot text, was a later attempt to reconcile Tosefta with the two Talmudim or may indicate how "burying Gentile dead" was interpreted in different periods of time. It is possible that poor Gentiles may have been given material help to bury their dead, but that responsibility for the actual ceremony, being either pagan or Christian, was not assumed by the Jewish community. Flavius Josephus supports the Tosefta and Talmudim in Against Apion, 2:30: "There are other things which our legislator ordained for us beforehand, which of necessity we ought to do in common to all men; to afford fire and water and food to all such as wants it; to show them roads, and not to let anyone lie unburied."

On the question of mourning/eulogizing, R. Jose states in tBer. 16b and jBer. 2:8 that one may say (as a eulogy?) "Alas good and faithful man," even though he might be a slave, if he is "worthy." The story of R. Gamaliel II's servant Tabi helps us to understand the meaning of kasher, "worthy" ( $\left.\mathrm{S}^{\mathrm{e}} \mathrm{m} .44 \mathrm{a}\right)$. R. Gamaliel mourned him after he died because during his lifetime he enjoyed a reputation among the Sages for his knowledge of Torah and his observance of the mitzvot. This attitude corresponds to the words of R. Eliezer: "We do not receive condolences for (ordinary) slaves." The question about Gentiles is posed to R. Jose: "What do we say of worthy men (Gentiles?) who are not slaves?" The Talmudim do not answer the question, but $S^{e}$ mahot continues: "If he is worthy why should we not say it (a eulogy) of him?" Once again, worthiness is a result of a person's relationship to the laws of the God of Israel.

We will consider the passage from tractate Gittin in the Jerusalem Talmud next. It is the most complete statement in oral tradition about the practice of gemilut hasadim towards Gentiles. The controversial statement in the last sentence is sometimes translated "bringing in utensils..." and sometimes as "giving dowries to brides...". The interpretation of 
$u$-makhnisin kblei goyim u-khlei Israel depends on the meaning of two Hebrew words which make up the phrase: makhnisin and kblei. Makhnisin generally meant "to bring in." The word however is used in the expression hakhnasat khalla to mean "giving dowries to brides" or "helping couples who wish to marry."

The interpretation of kblei is more problematic. Both the Jewish Encyclopedia ${ }^{18}$ and the Talmudic Encyclopedia ${ }^{19}$ in articles on gemilut hasadim understand this word as "utensils," as does Jacob Neusner in his translation of the Jerusalem Talmud ${ }^{20}$. It is true that in an agricultural society the care of animals and implements was important. A good neighbor would bring in a utensil that may inadvertently have been left out. Another reason to suppose that the translation could be "utensils" is that this passage appears only in the Jerusalem Talmud and not in the Babylonian. In the mixed population of Palestine at that time, relations between Jews and Gentiles in agricultural matters were common. On the other hand, an argument against the "utensils" translation is that this sentence does not appear in the Tosefta, which also developed in Eretz Israel. In Babylon, where the Jewish community lived a relatively autonomous life, there was less need for such legislation.

Another possible interpretation of kblei is discussed by Yehezkel Cohen, in a doctoral dissertation on relations between Jews and Gentiles in this period. He argued that the translation of kblei in this context should be "brides." He says that in eastern Aramaic the plural of kblei, "utensil," and the plural of khalla, "bride," is identical. In addition, the context, that is other acts of gemilut hasadim, deal with poor and needy persons and not with inanimate objects ${ }^{21}$. Translating "brides" rather than "utensils" is supported by the passages that speak of acts of gemilut hasadim towards Jews, where, if we can draw a parallel for Gentiles, deals with brides and not utensils. Whatever the worth of these arguments, most translations still use "utensils" rather than "brides" in this passage.

18. L. Rabbinowitz, “Gemilut Hasadim”, in Jewish Encyclopedia, New York, Ktav, 1975 (1901), vol. 7.

19. Talmudic Encyclopedia (Hebrew), Jerusalem, Talmudic Encyclopedia Publishing, 1956, vol. 7, p. $151 \mathrm{f}$.

20. J. Neusner, dir., The Talmud of the Land of Israel, Chicago/London, University of Chicago Press, 1982-1988, 35 vol.

21. See Cohen, The Attitude of the Gentile, p. 281. 
The problem for the Sages with helping Gentiles to marry lay in the implication of abetting an increase in pagan population ${ }^{22}$. On the other hand, it might seem natural in the context of daily life in Eretz Israel, where neighborly relations existed between Jews and Gentiles, especially in cities where taxes were collected from Gentiles, that needy Gentile couples, as well as Jewish couples, were funded.

Detailed directives are given with regard to the collection and distribution of funds for the Jewish poor. Two officials were appointed to collect funds and three to distribute them. In addition, three officials were named to collect for the soup kitchen, tambui, from which three meals for the Sabbath were distributed every Friday ${ }^{23}$. Since there is no mention of a special organization for the distribution of charity to Gentile poor, both Jewish and Gentile poor may have benefited from the same services.

As we have seen for other acts of gemilut hasadim, visiting Gentile sick would only be feasible within the context of a close-knit community of Jews and Gentiles. Visiting the sick and burying the dead posed a special problem because of the laws of ritual purity. Running sores or a dead body were important sources of impurity. In addition, the general question of Gentile impurity was in dispute among the Sages. The Jewish Encyclopedia cites passages from the Mishna ${ }^{24}$, Toseftah ${ }^{25}$ and Josephus ${ }^{26}$, which indicate that contact with Gentiles was indeed regarded as a source of ritual impurity before the 2 nd c. especially when the Temple existed. A. Buechler states:

As to the levitical impurity of the Gentile, it was instituted by the rabbis about the year 1 as a novelty going beyond the law in Lev. 15 [...]. The assumed levitical impurity of the Gentile affected, as the reports show, only the priest on duty, and the ordinary Jew only when purified for a visit to the Temple and for a participation in a sacrificial meal. The private asso-

22. A parallel situation is found in discussions about whether it is permitted for Jewish midwives to help Gentile women give birth. One of the arguments against it is that the Jewish midwife should avoid bringing another idol worshipper into the world. bAv.Zara 26a; tAv.Zara 3:9.

23. bB.B. 8 b.

24. mToh. 7:6; mNid. 10:4.

25. tPes. 7:13.

26. Josephus, Antiquities, 14:10:25; 18:5:3. 
ciations between the Jew and the Gentile were in no way restricted by the levitical purity ascribed to the Gentile ${ }^{27}$.

The consensus among the Sages after the second century seems to have been that contact with Gentiles did not render a Jew impure. It is reasonable to suppose, then, that the ritual impurity of Gentiles did not greatly affect the practice of gemilut hasadim towards them, since these mitzvoth evolved after the 2 nd c.

Praying for the recovery of a Gentile or wishing him/her well is connected with the question of whether the same attention was paid to the feelings of Gentiles as to that of Jews. If the character of the Gentile warranted such treatment, he was probably treated like any Jewish person in need. An analogy might be drawn from the fact that blessings were called down on the crop of a Gentile during the sabbatical year, when Jews did not cultivate the land. On the other hand, it may have been easier to pray for a good crop since it benefited both communities. The same may not hold true for a Gentile sick person. However, praying for his/her recovery probably depended once again on the circumstances of the particular case. "Worthiness" as we have seen in the discussion on burial rites, may once again have served as a criterion here.

Provisions for assistance to Gentiles included not only physical but also spiritual help. Comforting mourners is explicitly mentioned in the story of R. Meir and his Gentile friend, Aptimos of Gadara, for example $^{28}$. The detailed prescriptions for other mitzvoth, such as rejoicing with newly married couples, or saying blessing for the dead or at a wedding may have been, if an analogy can be drawn from passages which prescribe mourning Jewish dead or rejoicing at a wedding, also part of the observance of gemilut hasadim towards Gentiles.

In general, it can be assumed that these mitzvoth were based on customs that were actually practiced within Jewish communities. The motive given in these passages for the observance of the acts of gemilut hasadim towards Jews and Gentiles is "for the sake of peace," mippenei darkhei shalom. The importance of a law in Oral Tradition often depends on whether it is directly derived from written Torah, de-'oraita, or from a rabbinic decree, de-rabannan. "For the sake of peace" according

27. A. BüChlen, “The Levitical Laws of Impurity of the Gentile Before 70," The Jewish Quarterly Review, n. s. 17 (1926-1927), p. 80.

28. Ruth R. 2:3. 
to R. Joseph in answer to a question from Abaye is derived directly from Torah: "The whole of the law is for the purpose of promoting peace, as it is written 'Her ways are ways of pleasantness and all her paths are peace' (Prov. 3:17)" (bGit. 59b). According to R. Simon b. Gamaliel, "the world is founded on three things: on judgment, truth and peace, and these three are one" (bBer. 64a; jTa'anit 4:2.68a). In aggadic tradition Elijah will return to bring peace to the earth, as will the Messiah (bSanh. 99b; bBer. 17a; Perek HaShalom 59b).

Many acts in Oral Tradition are done "for the sake of peace." Torah is studied for its own sake or "for the sake of peace" (bYeb. 65b). Shalom, the ordinary Jewish greeting is a prayer for peace (jBer. 2:1, 4b). One can deviate from the strict truth in order not to disturb someone's peace or to establish peace where it does not exist (bShab. 10b; Lev. R. 9:9). Peace in the family or among nations is mentioned many times (e.g. jSot. 1:4,16d).

Aaron is the ideal peacemaker in the opinion of the Sages. Hillel says in P.Avot 1:12: "Be disciples of Aaron, love peace, pursue peace, love all mankind and draw them to the Torah." Aaron provoked the Israelites to perform acts of gemilut hasadim by his charity. Pirkei de-Rabbi Eli'ezer 19a:2 says of Aaron: "He loved peace and pursued peace, and passed through the entire camp of Israel and promoted peace between a man and his wife, and between a man and his neighbor." As a sign of his preeminence in this area, all Israel, men, women, and children wept for him after his death, whereas only the men wept for Moses. Finally, the highest indication of its importance for the Sages is that shalom was listed as one of the names of God (bBer. 60b).

It has been suggested that "for the sake of peace" in connection with acts of gemilut hasadim towards Gentiles had a negative connotation, that is, to avoid the hostility of non-Jews. There may some basis for this view, especially since we find a sharper expression used later in circumstances where "for the sake of peace" may previously have sufficed. The Sages, during the Byzantine period in the fourth century, tended to use the expression "to avoid hostility," mippenei eiva, when accepting gifts from Gentiles, doing business around the time of Gentile festivals or attending a wedding dinner of a Gentile's son (if the food was kosher) (bAv.Zara 6b; bB.M. 32b).

It is important to note that the expression "for the sake of peace" was also used in internal Jewish matters. It was used in situations which could 
produce jealousy and backbiting within the Jewish community, for example in halakhot which deal with the order of "going up to the Torah" in the synagogue, relations among families who share a central courtyard, 'eruv, use of water resources, or the placing of animal and bird snares.

Mippenei eiva also occurs in internal Jewish matters such as property settlements in divorce cases, when children are left orphans, concerning laws of purity and finally when dealing with professional errors made in the course of their duties by a priest, doctor or court official.

Other instances where Oral Tradition lays down rules "for the sake of peace" include greeting Gentiles and shaking hands during the sabbatical year (mGit. 5:9). In his commentary on the Mishna ${ }^{29}$, Chanoch Albeck says that since the Gentiles are not obliged to observe the sabbatical year, besides greeting them if they are working in their fields, they should be wished a fruitful harvest "for the sake of peace." Pinchas Kehati, in his commentary ${ }^{30}$, adds that on their festivals even though they engage in idol worship, they should be greeted "for the sake of peace." Rabbi Yohanan b. Zakkai always took the initiative in greeting people, even a Gentile in the market (P.Avot 1:18).

If "for the sake of peace" was the main motivation for the performance of acts of gemilut hasadim towards Gentiles, other positive reasons could also have played their part. The responsibility of the Jewish people to witness to the holiness of the Name of God and thus draw Gentiles under the "wings of the Shekhina" was an added incentive for performing acts of loving-kindness towards non-Jews in aggadic traditions.

The following two examples of the practice of loving-kindness towards Gentiles reveal the importance of this mitzvah in the eyes of the Sages. Not only are two eminent Biblical personages involved, Abraham and Sarah, but also the acts themselves are unusually intimate. The story of Abraham serving a meal to angels whom he thought were pagan Arabs, and who in addition, were rich and did not need it, is recounted several times in aggadic stories: "R. Joshua: Abraham served the ministering angels when he thought that they were pagan Arabs ${ }^{31}$." Sarah, at

29. C. Albeck and H. Yalon, Shisha Sidre Mishnah, Jerusalem, Bialik Institute, 19521956, 6 vols.

30. P. Kehati, Mishnayot, Jerusalem, Heichal Shlomo, 1977.

31. Sifrei Deut. (Ekev) 11:38. 
the instigation of Abraham, suckled Gentile children, even after their Gentile parents had told lies about her giving birth to Isaac ${ }^{32}$.

R. Berechiah, citing R. Levi, said:

You find that when our mother Sarah gave birth, the nations of the world declared-and may we be forgiven for repeating what they said—: Sarah did not give birth to Isaac, it was Hagar, Sarah's handmaid. [...] [To prove that Sarah had indeed given birth to Isaac], what did the Holy One do? He withered up the nipples of the noblewomen of the world's nations, so that they came and kissed the dust of Sarah's feet and pleaded with her: Do a good deed and give suck to our children. Thereupon, our father Abraham said to Sarah, [...] Hallow the Holy One's Name. Sit down in the marketplace and give suck to their children ${ }^{33}$.

tPe'ah 4:21 asks why tzedaqah and gemilut hasadim are great peacemakers between Israel and their Father in heaven. The answer is derived from Jer. 16:5: when they do not perform acts of kindness, God is displeased with Israel. As a result, he takes away "my peace from this people, says the Lord, my steadfast love (hesed) and mercy". When Israel performs acts of charity and peace once again reigns. The Tosephta interprets Jeremiah as follows: "hesed (in Jeremiah) is gemilut hasadim and mercy is tzedaqah, which teaches that these two bring peace between God and Israel."

\section{Conclusion}

Two separate requirements of Jewish life vied with each other for supremacy on the question of relationship with Gentiles: preservation of Jewish identity, at that time assailed on every side, was of primary importance, and the fulfillment of the Divine command to witness to the sanctity of God's name. It is therefore surprising that the passages in Oral Tradition that deal with the practice of gemilut hasadim towards nonJews are ancient and authoritative halakhoth. They draw a clear parallel between acts of loving-kindness performed towards Jews and Gentiles,

32. Christians claimed that they were the spiritual heirs of Isaac and that the Jews were the children of Hagar. Cf. Gal. 4:24-25.

33. Pesikta of R. Kahana, Piska 22 (Sus Assis). Cf. also Shimon b. Shetah_'s witness to the Gentile in jB.M. 2:8c and Deut. R. 3:5.Jews and the Nations: the Clash of Civilizations 
but they do not define in detail the prescriptions of this mitzvah towards non-Jews. Since Oral tradition is based on the concrete demands of daily living, the basic orientation was given in the passages quoted above, while the detailed application of each mitzvah depended on the relationship of the Gentile to the God and people of Israel, as well as on the personal relations between the Jewish and Gentile communities in any particular locality, or on the relationship between an individual Jew and an individual Gentile. In view of the fact that "for the sake of peace" was the main reason for the practice of gemilut hasadim towards Jews and Gentiles, the importance of this mitzvah in Jewish tradition to "repair the world" and to bring all persons "under the wings of the Shekhina" can be all the more appreciated.

\section{List of rabbinic works and key to abbreviations}

\section{Abbreviations prefixed to tractates}

b

j

$\mathrm{m}$

$\mathrm{t}$
Babylonian Talmud (E.g. bKet. = Babylonian Talmud, tractate Ketuboth)

Jerusalem Talmud

Mishna

Toseftah

Tractrates of the Mishna, Talmudim or Tosefta:

Av.Zara

Avot

A. de R. Nathan

B.B.

B.M.

Ber.

Demai

Git.

Hag.

Ket.

Men.

Nez.

Nid.

Pe'ah

Perek Hashalom

Pes.
Avodah Zara (deals with idolatry) (see P. Avot)

Avot de-Rabbi Nathan (a commentary on Avot)

Baba Bathra (property law)

Baba Metzia (civil law)

Berakhot (blessings)

$\mathrm{D}^{\mathrm{e}}$ mai (tithe for "dubious" fruits)

Gittin (divorce)

Hagigah (the festival offering)

Ketuboth (marriage contracts)

Menahot (meal offering)

Nezikin (damages)

Niddah (the menstruant)

Pe'ah (gleanings)

Perek Hashalom (chapter on peace)

Pesahim (Passover) 
P. Avot

Sanh.

Sem.

Shab.

Shevi'it

Sot.

Suk.

Ta'anit

Ter.

Toh.

Yeb.

Yom
Pirkei Avot (Sayings of the Fathers)

Sanhedrin (judges)

Semahot (rejoicing)

Shabbat (the Sabbath)

Shevi'it (Sabbatical Year)

Sotah (the suspected adulteress)

Sukkah (the feast of Tabernacles)

Ta'anit (Fast Days)

Terumoth (heave offerings)

Toharoth (ritual cleanness)

Yebamoth (levirat marriage)

Yoma (the Day of Atonement)

Midrashic and haggadic works

Deut. R. Deuteronomy Rabba

Lev. R. Leviticus Rabba

Mek. Mekhilta (midrash on Exodus)

Num. R. Numbers Rabba

Peskita de R. Kahana Peskita de-Rabbi Kahana

Pirkei R. Eliezer Pirkei de-Rabbi Eliezer

Ruth R. Ruth Rabba

Sifrei Deut. Sifrei on Deuteronomy

Siphra Siphra (midrash on Leviticus)

Transliteration of Hebrew letters

$\begin{array}{ll}, & \text { Aleph } \\ \text { ayin } \\ \text { a } & \text { Hei at the end of a word } \\ \text { ah } & \text { Aleph at the end of a word } \\ \text { e } & \text { vocal Sheva } \\ \mathrm{h} & \text { Khet } \\ \mathrm{kh} & \text { Kaph } \\ \mathrm{q} & \text { Qoph } \\ \mathrm{tz} & \text { Tzadeh }\end{array}$




\section{RÉSUMÉ}

Le commandement d'aimer son prochain qu'on trouve dans la Bible hébraïque a été interprété par les sages d'Israël en fonction du contexte historique dans lequel ils se trouvaient. Pendant les six premiers siècles de l'ère courante, le peuple juif a été confronté à une réalité radicalement nouvelle. Il a dû faire face en même temps à la destruction du Temple, base de sa vie religieuse, et à un accroissement significatif des contacts avec les non-Juifs; il en est résulté un effort de consolidation des normes traditionnelles. On a codifié dans la Mishna, la Tosephta et les Talmuds de Jérusalem et de Babylone des préceptes concernant l'amour du prochain, Juif et non-Juif. Cet article explore diverses applications du précepte de l'amour à l'égard du prochain non-juif dans la tradition juive ancienne. Leur étude peut fournir un point de départ à de plus amples discussions au sujet d'un aspect du judaïsme méconnu de bien des non-Juifs.

\section{ABSTRACT}

The Hebrew Scriptures' command to love one's neighbour was interpreted by the early Sages of Israel in light of the historical context in which they lived. During the first six centuries of the Common Era, a radically new reality confronted the Jewish people. Faced both with the destruction of the Temple, the basis of religious life, and increased contact with Gentiles, a consolidation of traditional norms was undertaken. Precepts concerning love of the Jewish and non-Jewish neighbour, were codified in the Mishna, Tosephta and the Jerusalem and Babylonian Talmudim. This article explores some of the details of the precept of love of neighbour towards nonJews in early Jewish tradition. It may provide a springboard for further discussion about an aspect of Judaism with which many non-Jews might not be familiar. 